Article

\title{
Geochemical Study of Weathered Coal, a Co-Substrate for Bioremediation of South African Coal Discard Dumps
}

\author{
Yvonne van Breugel ${ }^{1}$, Ashton Keith Cowan ${ }^{1}\left(\mathbb{D}\right.$ and Harilaos Tsikos ${ }^{2, *}$ \\ 1 Institute for Environmental Biotechnology, Rhodes University, Makhanda (Grahamstown) 6140, \\ South Africa; y_vanbreugel@yahoo.com (Y.v.B.); a.cowan@ru.ac.za (A.K.C.) \\ 2 Department of Geology, Rhodes University, Makhanda (Grahamstown) 6140, South Africa \\ * Correspondence: h.tsikos@ru.ac.za; Tel.: +27-46-603-8011
}

Received: 28 October 2019; Accepted: 8 December 2019; Published: 11 December 2019

check for updates

\begin{abstract}
Coal mining creates large volumes of waste in the form of discard coal that is stockpiled. In South Africa, rehabilitation of coal discard dumps remains a challenge due to reliance on topsoil for establishment of vegetation. Exploitation of fungal bio liquefaction/degradation of coal resulted in the emergence of Fungcoal as a bioprocess for the rehabilitation of coal discard dumps and opencast spoils. In this process, a suite of fungi is used to bio liquefy/degrade recalcitrant waste coal to form a soil-like material which promotes reinvigoration of the microbial component, grass growth, and re-vegetation. Here, the role of outcrop weathered coal as a mineral/carbon source to ensure biologically induced humic acid-like substance enrichment of discard and spoil to increase efficacy of fungi-plant mutualism and stimulate revegetation without the need for topsoil was investigated. Mineralogical, elemental, and pyrolysis gas chromatography-mass spectroscopic analyses show that outcrop weathered coal has decreased volatile material and increased humics, ash, and mineral bound water in comparison to bituminous coal. These changes occur coincidently with decreased $\mathrm{C}, \mathrm{N}$, and $\mathrm{H}$ contents, and a substantial increase in $\mathrm{O}$ concentration. No apparent stoichiometric relationship between sulphur and iron oxide content of weathered coal could be discerned suggesting little residual pyrite in this material and a dominance of oxy-hydroxides of Fe. Organic analysis showed weathered coal to be enriched in C-16 and C-18 fatty acids and the presence of the indicator, $17 \alpha(\mathrm{H}), 21 \beta(\mathrm{H})$-homohopane but not the $\beta, \beta$-stereoisomer, was interpreted to indicate that bacteria may only have been active prior to transformation of hard coal into weathered coal.
\end{abstract}

Keywords: coal; discard dumps; rehabilitation; weathered coal; geochemistry; pyrolysis gas chromatography-mass spectrometry

\section{Introduction}

Coal mining is the process of extracting coal from the ground. Coal is valued for its energy content, and, since the 1880s, has been widely used to generate electricity [1]. However, extraction, processing, marketing, and the sale of coal generate large quantities of low-grade waste that is of little or no apparent immediate commercial value. Although stockpiled in discard dumps which are highly engineered disposal sites, storage of this uncharacterized heterogeneous low-value material has both short- and long-term impacts on the environment. Left unattended, coal discard dumps are major contributors to atmospheric pollution, contamination of surface and ground water by acid leachate runoff, erosion and sedimentation of particulates into adjacent rivers and dams, spontaneous combustion, and landslides [2]. Similarly, once mineral extraction is complete overlying spoils are returned to the void in both underground and opencast mining. Revegetation of this disturbed land and 
stabilization of discard dumps is in many cases a very necessary, difficult, and costly exercise. A major challenge faced by the coal mining industry, therefore, is to develop and implement efficient strategies to mitigate the negative impacts of mining and stockpiled waste on the environment throughout the lifecycle of operation-from design and production to eventual mine closure [3,4]. The affected areas in South Africa should be restored to an agreed land capability and land use at time of mine closure to limit impact on the environment and surrounding communities [5].

Commercially mined South African coals have a very wide range of volatile matter content, although the coal quality generally falls within a narrow range of bituminous coal (steam coal), when based on vitrinite reflectance [6-10]. For these coals that are rich in ash and inertinite, and highly variable in type, grade, and rank, a classification based on elemental carbon and hydrogen (wt\% dry, ash-free) has been proposed [11,12]. Even so, and perhaps as a consequence, a large amount of discard and slurry is generated by the South African industry. In 2001 the Energy Branch of the Department of Minerals and Energy commissioned an inventory of discard and duff coal in South Africa [13]. The outcome: annual production rates in excess of 42 million and 11 million tonnes for discard coal and slurry, respectively; annual discard production increased from 43.6 million to 66.2 million tonnes between 1985 and 2001; and, it was estimated that total produced and dumped discard registered 1,120,853 million tonnes by 2001 and covered an area of 4011 ha. Typically, this low-grade coal has an energy value lower than $15 \mathrm{MJ} / \mathrm{kg}$ and high ash content (i.e., $>50 \mathrm{wt} \%$ ) and, when either combusted or stockpiled/abandoned, these coals pollute the environment.

Over the years, it has become increasingly important to gain better insight into the molecular structure and mineral matter of coal, for both coal beneficiation and to mitigate detrimental effects from its use and storage. More emphasis has since been placed on the chemical structure using techniques such as pyrolysis-gas chromatography-mass spectrometry (pyr-GC-MS) [14,15], and nuclear magnetic resonance (NMR) spectrometric analysis [16-22], among others. Interest in lower-grade coal has also increased because of its potential as a soil amendment product which has particular relevance to the work described here.

Many studies of low-grade coals focus on lignite and laboratory-oxidized (usually nitric acid) coals to determine identity of weathering products and potential beneficiation strategies [16,17]. The fate of organic material in weathered coal and other organic-rich rocks has also been studied largely to improve modelling of the carbon cycle [18,19]. In contrast, few (if any) in situ studies of weathered coal have been undertaken. Even so, we recently showed that outcrop weathered coal was an ideal co-substrate in a bioprocess that utilizes the mutualistic interaction between coal degrading and mycorrhizal fungi and bespoke grasses in the vegetation of discard dumps [20]. Indeed, other forms of weathered coal including coal from discard dumps and a highly oxidized coal obtained from an aged waste dump were unable to support fungal-plant bioremediation and revegetation [20]. Thus, the geochemical study of outcrop-weathered coal described here was undertaken to provide insight into the role of this material as a mineral/carbon source to ensure biologically induced humic acid (HA)-like substance enrichment of discard and spoil to facilitate breakdown of the carbonaceous material [21-23], plant-fungal mutualism [24,25], and revegetation without the need for topsoil [20,26]. Furthermore, a good understanding of the geochemistry of this outcrop weathered coal may improve our understanding of the geological processes involved in coal weathering in situ.

\section{Materials and Methods}

\subsection{Sample Collection and Preparation}

Weathered coal samples were sourced from Landau Colliery (Kromdraai Opencast, latitude $25^{\circ} 46^{\prime} \mathrm{S}$; longitude $29^{\circ} 4^{\prime} \mathrm{E}$ ) in the Emalahleni coalfield of South Africa. Samples were collected along a vertical transect of outcrop (No 2 Seam, Kromdraai Section) at $10 \mathrm{~cm}$ intervals, spanning $1 \mathrm{~m}$ of weathered coal and showing visible decline in the degree of weathering with depth (Figure 1). An additional outcrop weathered coal sample (WC-03/12) and a composite sample of fragmented hard 
coal (HC-05/12) were obtained from the Kromdraai opencast operation (Landau Colliery). The outcrop hard coal sample, together with a hard coal sample from the Navigation Plant at Landau Colliery (HC-NP) were used as end member, non-weathered reference samples. Prior to processing for mineralogical and geochemical analyses, visible roots and other undecomposed biological debris were manually removed from all field samples. Subsequently, the samples were freeze-dried and milled to a grain size of $\leq 0.2 \mathrm{~mm}$.

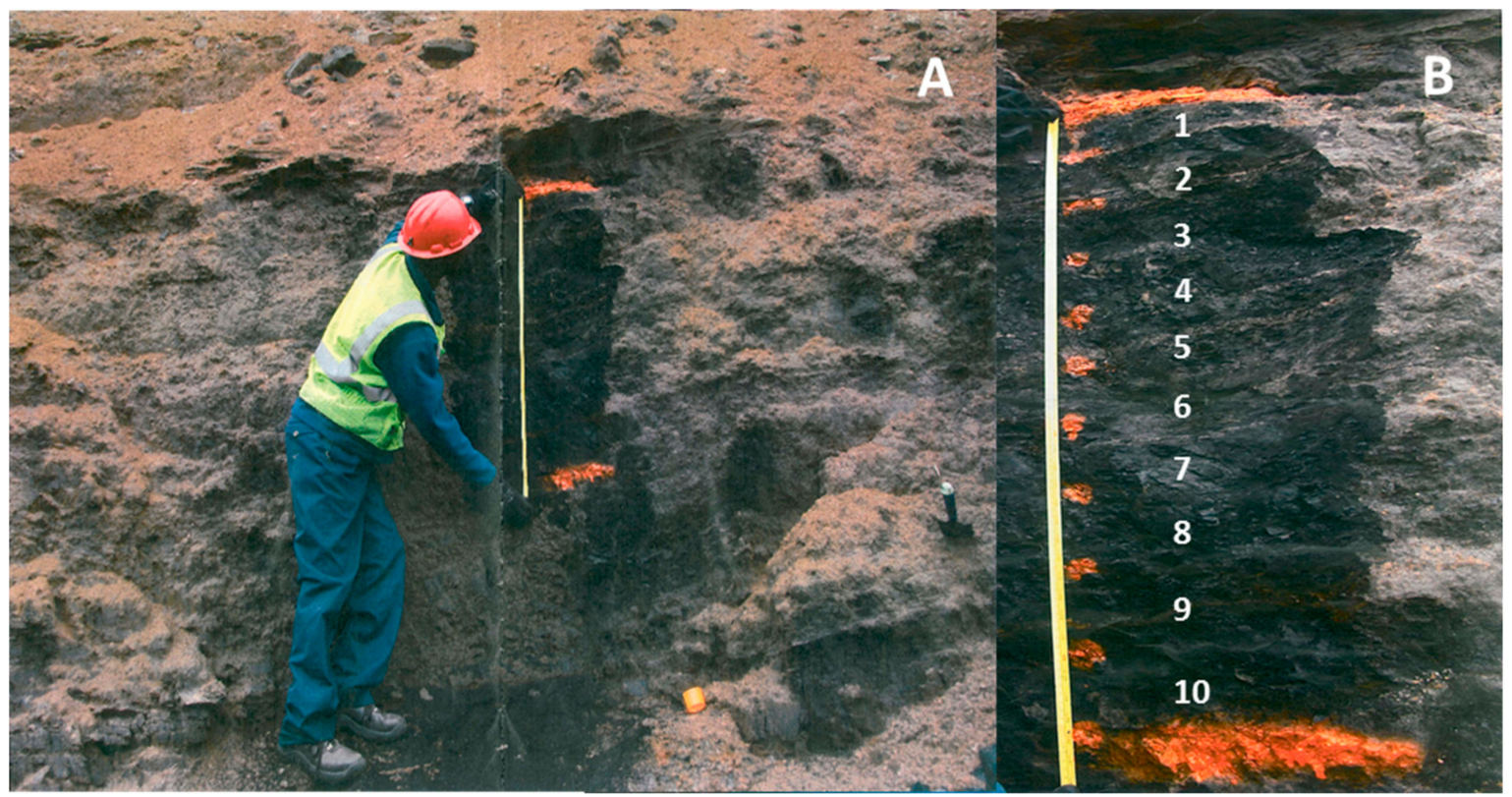

Figure 1. Vertical transect on outcrop weathered coal at Kromdraai Opencast, Landau Colliery (A) and, indication of sampling points at $10 \mathrm{~cm}$ intervals from the top (B).

\subsection{Analytical Techniques and Procedures}

Bulk mineralogical, inorganic, and organic geochemical analyses were performed on pulverized samples of weathered and hard coal. All raw analytical data used and displayed in this paper are archived in the Supplementary data file. Mineralogical determinations were obtained via standard X-ray diffraction (XRD) methodology using a Bruker instrument at the Department of Chemistry, Rhodes University. Total carbon, oxygen, nitrogen, and sulphur data were obtained at the MINTEK geochemical laboratories (ASD-MET-C16/26) in combination with in-house elemental analyses at Rhodes University (PE 2400 CHNS/O, PerkinElmer, Waltham, MA, USA). Determination of inorganic elemental compositions required heating of aliquots of all samples at $900{ }^{\circ} \mathrm{C}$ for at least $6 \mathrm{~h}$, in order to determine the total loss on ignition (LOI). Major and minor elemental oxide analyses were then performed on fused glass discs and for trace elements on pressed powder pellets using a Phillips PW1480 X-ray fluorescence (XRF) spectrometer in the Geology Department at Rhodes University.

Extraction of humic substances (HS) were performed on outcrop weathered coal and hard coal (sample no. 5, 7, 8, 9, 10,11, and 12) on the basis of humin content. Following method optimization, weight percentage composition of HA, fulvic acids (FA), and humin in the samples was determined in duplicate. Samples were initially extracted three times by sonication in $5 \mathrm{~mL}$ of MeOH:DCM (1:1 v/v) and twice by sonication in $5 \mathrm{~mL}$ DCM and, after centrifugation to derive the DCM-soluble material, the freeze-dried pellet suspended in $40 \mathrm{~mL} 0.1 \mathrm{M} \mathrm{NaOH}$. The suspension was agitated for $24 \mathrm{~h}$ at $150 \mathrm{rpm}$ $\left(28^{\circ} \mathrm{C}\right)$ and centrifuged at $3220 \times g$ at $10^{\circ} \mathrm{C}$ for $30 \mathrm{~min}$. The pellet was washed $(2 \times)$ with $30 \mathrm{~mL} 0.1 \mathrm{M}$ $\mathrm{NaOH}$, and the supernatants pooled. The final pellet (humin) was freeze-dried and weighed. The $\mathrm{pH}$ of the supernatant was adjusted using concentrated $\mathrm{HCl}$ to $<2$ and allowed to stand for at least $1 \mathrm{~h}$ to precipitate HA after which it was centrifuged at $3220 \times g$ at $10{ }^{\circ} \mathrm{C}$ for $30 \mathrm{~min}$. The process was repeated 
until the soluble HA component was less than $0.1 \mathrm{mg}$. The FA-containing supernatant was analyzed spectrophotometrically at $280 \mathrm{~nm}$ while the HA-containing pellet was freeze-dried and weighed.

For determination of volatiles, mineral-bound water, and ash content, the humin fraction was dried at $100{ }^{\circ} \mathrm{C}$ overnight to a constant weight and then heated at $400{ }^{\circ} \mathrm{C}$ for at least $4 \mathrm{~h}$ using a muffle furnace. The samples were then heated at $900{ }^{\circ} \mathrm{C}$ for $6 \mathrm{~h}$ to determine the mineral-bound water and the ash fraction. All data are expressed as weight percentage of the whole sample and recovery after fractionation was $\geq 97 \%$.

Structural changes in the HA component were investigated by analysis of the MeOH:DCM-soluble compounds by GC-MS and by flash pyr-GC-MS analysis. The latter has been shown to provide valuable information for structure elucidation of HA [14,27-29]. Methods used for the derivatization and pyrolysis of the freeze-dried HA extract follow Martin et al [30]. and Lehtonen et al [31,32]. A 25\% aqueous solution of tetramethylammonium hydroxide at a 2:1 ratio was added to 0.5-1 mg of the extracted HA in a quartz tube supported at both ends with fussed silica wool (Restek, Cat. no. 24324). Poly(tert-butylstyrene) $(1 \mu \mathrm{L}, 0.05 \mathrm{mg} / \mathrm{mL}$ in hexane) was introduced to serve as an internal standard. Samples were then dried at $100{ }^{\circ} \mathrm{C}$ for $10 \mathrm{~min}$. The sample was pyrolyzed at $700{ }^{\circ} \mathrm{C}$ for $15 \mathrm{~s}$ in a CDS 5000 Pyroprobe series with CDS 1500 valve interface (CDS Analytica, Inc, Oxford, PA, USA) that was kept at $250{ }^{\circ} \mathrm{C}$ and purged continuously with helium gas at $1.5 \mathrm{~mL} / \mathrm{min}$. The $6890 \mathrm{~N}$ gas chromatograph system (Agilent Technologies, Santa Clara, CA, USA) was programmed to ramp from 60 to $200^{\circ} \mathrm{C}$ at $6{ }^{\circ} \mathrm{C} / \mathrm{min}$ and then at $10^{\circ} \mathrm{C} / \mathrm{min}$ to $300{ }^{\circ} \mathrm{C}$, where it was held for $2 \mathrm{~min}$. The system was set in split mode 2:1 with a 3 min solvent delay time. The capillary column (Agilent 19091s-433) specification was as follows: $30 \mathrm{~m}$ (length) by $250 \mu \mathrm{m}$ (internal diameter) with a film thickness of $0.25 \mu \mathrm{m}$. Four sample replicates were used and detected with the MS 5975 inert Mass Selective Detector using the parameters $70 \mathrm{eV}, 1.7 \mathrm{kV} \mathrm{SEV}, 1.1 \mathrm{~s}$ scan rate. The identification of the pyrolysis products was based on NIST library search and some of the selected spectra confirmed using standards. The results were evaluated qualitatively and semi-quantitatively as described by Fabbri et al [33].

\section{Results}

\subsection{Bulk Characterization of Kromdraai Weathered Coal}

Results from samples of weathered coal from Seam 2 show clear small-scale variation in the content of organic and inorganic material (Figures 2 and 3). The organic fraction i.e., total carbon, HA, and humin (volatile material), decreases in a broad trend from the base of the transect (i.e., $1 \mathrm{~m}$ below surface) towards the top of the weathered coal profile (Figure 2). A localized increase at 40-30 cm from the top of the profile probably reflects enrichment with fine biological litter that was not successfully removed prior to sample processing. Even so, the pattern of carbon distribution within the profile is consistent with the idea that soil organic carbon levels are higher at depth than at or near surface, i.e., generally 1.5-2 times higher at depths $>1 \mathrm{~m}$ compared to the top $1 \mathrm{~m}$. The volatile fraction, or refractory organic fraction of coal, was highest in the lowermost samples at contents as high as $9.8 \mathrm{wt} \%$, while from $70 \mathrm{~cm}$ upwards the same content declined to values lower than $1 \mathrm{wt} \%$.

Measured carbon content ranges between 11 and $52 \mathrm{wt} \%$ of the bulk sample mass, and is shown to co-vary linearly with the organic fraction $\left(\mathrm{R}^{2}=0.95\right)$ (Figures 3 and $4 \mathrm{~b}$ ). Carbon in the HA fraction exhibits little variance across the selection of samples analyzed $(5,7,8,9$, and 10) and, at 54-64 wt\% of the bulk sample, most of the carbon is hosted in the organic fraction (Figures 3 and $4 \mathrm{~b}$ ). Total nitrogen decreases progressively from $0.94 \mathrm{wt} \%$ at $100 \mathrm{~cm}$ to $0.29 \mathrm{wt} \%$ at $50 \mathrm{~cm}$, with all nitrogen apparently bound to the HA fraction of the same sample set. In a similar fashion to total carbon, nitrogen content increases from $0.6 \mathrm{wt} \%$ at 30-40 cm, with lower concentrations registered again in the top $20 \mathrm{~cm}$ $(0.3 \mathrm{wt} \%$; Figure 3$)$. The change in nitrogen content along the weathered coal outcrop transect correlates closely with the organic fraction at $\mathrm{R}^{2}=0.93$ (Figure $4 \mathrm{~b}$ ), which confirms that most of the nitrogen in the weathered coal is organic-bound. Oxygen concentration increases slightly from mean values of $26.5 \mathrm{wt} \%$ in the bottom $50 \mathrm{~cm}$ to $30.9 \mathrm{wt} \%$ in the top $50 \mathrm{~cm}$, despite the fact that weathering of 
coal should increase oxygen content of HA [34]. Based on the five HA samples analyzed for total oxygen, an average of $92 \mathrm{wt} \%$ oxygen was determined to be inorganic-bound, with a higher amount of organic-bound oxygen recorded towards the bottom of the profile.

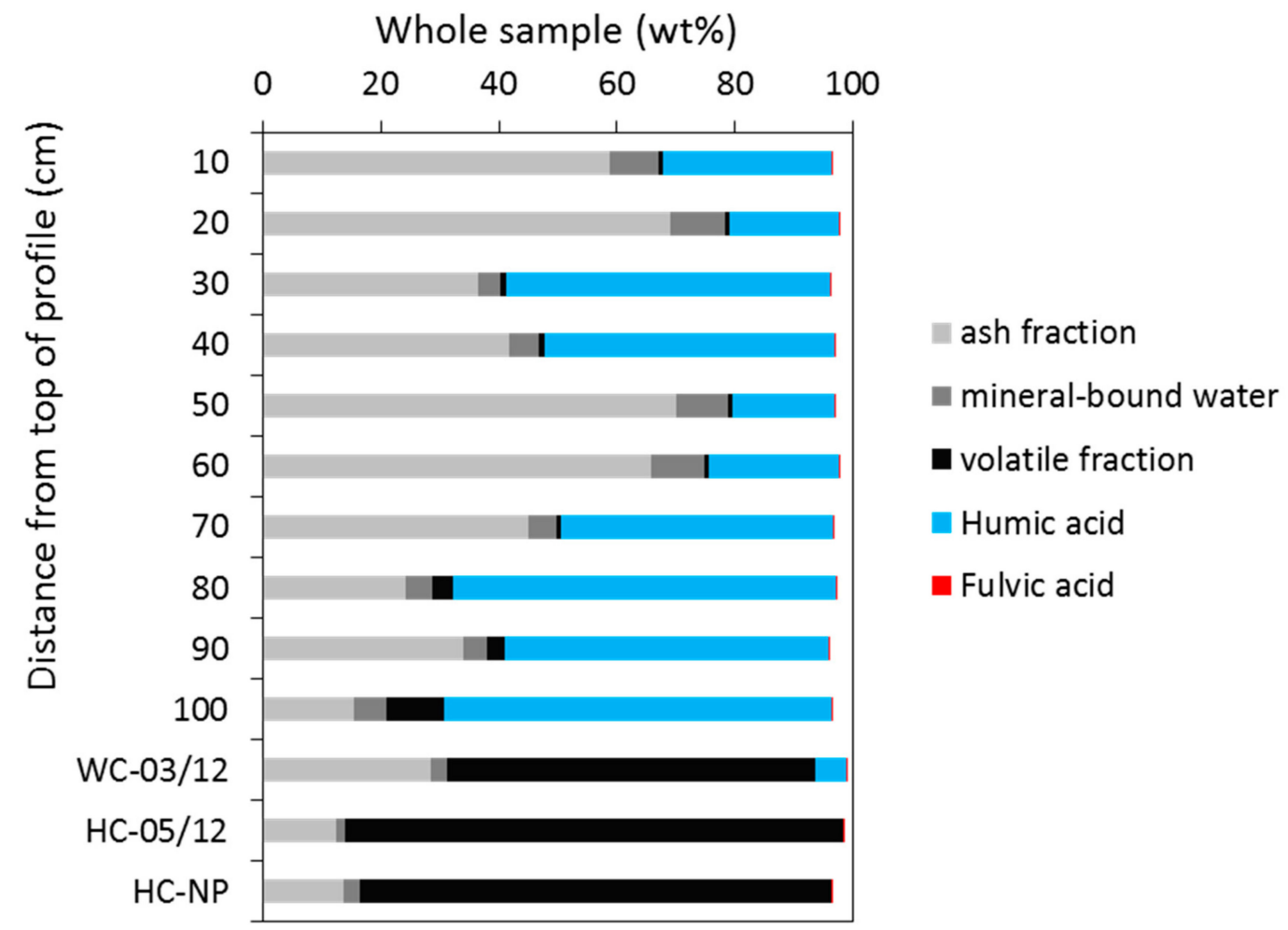

Figure 2. Fractional composition of samples obtained along a vertical transect of weathered outcrop and of hard coal from Kromdraai Opencast, Landau Colliery. WC-03/12 is a weathered coal sample obtained in March 2012; HC-05/12 a hard coal sample from May 2012, HC-NP is a composite hard coal sample from Navigation Plant, Landau Colliery.

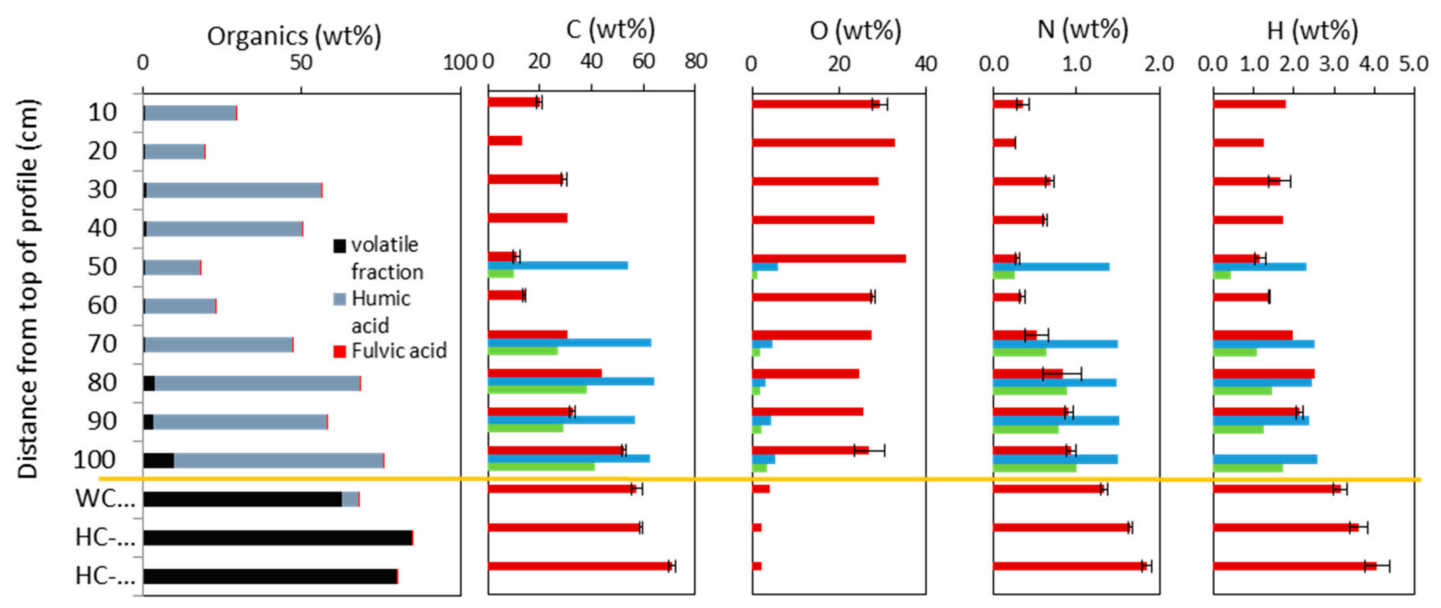

Figure 3. Carbon, oxygen, nitrogen and hydrogen concentration in samples from a vertical transect of weathered coal outcrop expressed as weight percentage of the total sample (red bars). Additionally, also shown are the $\mathrm{C}, \mathrm{O}, \mathrm{N}$, and $\mathrm{H}$ contents of the humic acid ( $\mathrm{wt} \%$ of $\mathrm{HA}$ fraction; blue bars) as weight $\%$ of the total sample (green bars). WC-03/12 is a weathered coal sample obtained in March 2012; HC-05/12 a hard coal sample from May 2012, HC-NP is a composite hard coal sample from Navigation Plant, Landau Colliery. 

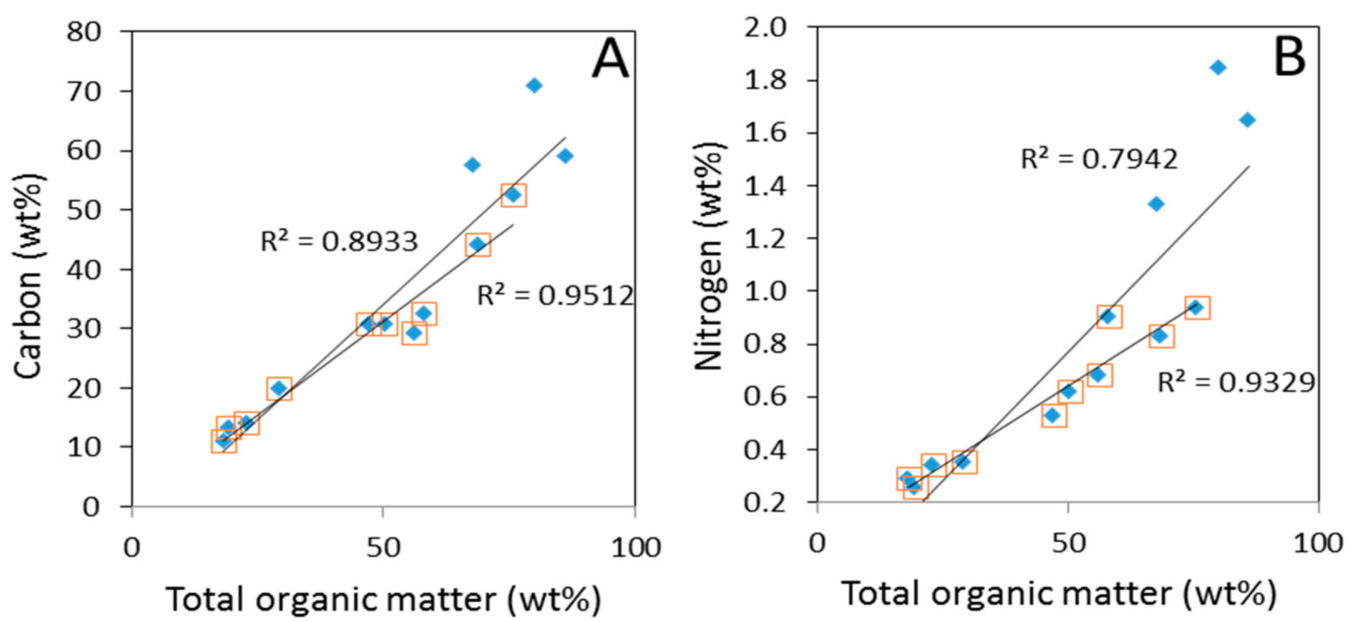

Figure 4. Relationship between concentration of carbon (A) nitrogen (B), and organic matter content (humic acid + fulvic acid + volatile material) of weathered coal. Red open squares are samples from weathered coal profile showing linear correlation of $R^{2}=0.95$ and 0.93 , respectively. Blue diamond shapes include hard and weathered coal samples, showing a correlation with, respectively, $\mathrm{R}^{2}=0.89$ and 0.79 .

The sulphur content of outcrop weathered coal samples is very low $(<0.07 \mathrm{wt} \%)$, except for the sample at $90 \mathrm{~cm}$ where the bulk sulphur concentration is $0.29 \mathrm{wt} \%$ (Figure 5). Sulphur in this sample is about $70 \%$ inorganically bound. Similarly, iron oxide was detected in minor amounts at each sampling interval along the weathered coal transect $\left(\mathrm{Fe}_{2} \mathrm{O}_{3}<1.86 \%\right)$ but, at the $90 \mathrm{~cm}$ sampling point the concentration increases to $11.4 \mathrm{wt} \%$ (Figure 5). Even at this specific level, no clear stoichiometric relationship exists between sulphur and iron content, pointing to low preservation of residual pyrite relative to the oxy-hydroxides of $\mathrm{Fe}$ which are expected to have been produced through pyrite breakdown. This is supported by the hard coal reference sample HC-05/12, in which elevated sulphur content $(11.6 \mathrm{wt} \%)$ corresponds with high iron $(23.7 \mathrm{wt} \%)$, indicating the primary prevalence of pyrite (Figure 5).

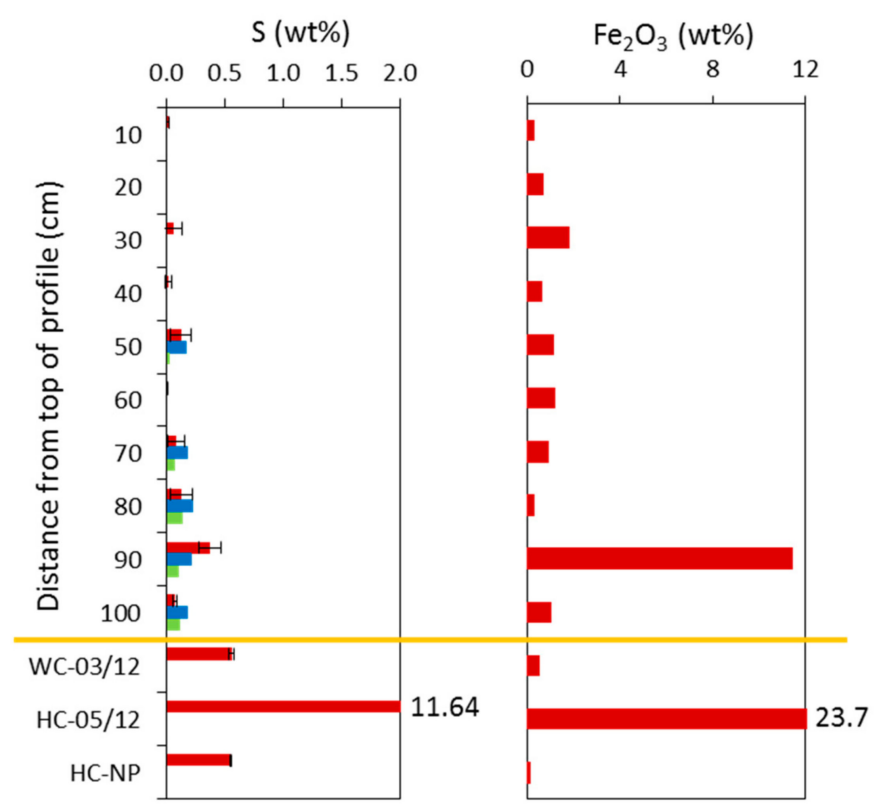

Figure 5. Sulphur and iron concentration in samples from a vertical transect of weathered coal outcrop expressed as weight percentage of the total sample (red bars). Sulphur in the humic acid fraction is expressed as $w \mathrm{t} \%$ of both the humic acid fraction (blue bars) and total sample (green bars). 


\subsection{Inorganic (Ash) Geochemistry}

The inorganic (ash) fraction of the two hard coal samples was determined at 12.4 and $13.8 \mathrm{wt} \%$ of the bulk, which is consistent with the range ( $8-35 \mathrm{wt} \%)$ of mineral matter reported for coal from the Emalahleni Coalfields [35]. By contrast, ash content rises to as high as $70 \mathrm{wt} \%$ in the weathered coal profile (Figure 2). Two elemental oxides, namely $\mathrm{Al}_{2} \mathrm{O}_{3}$ and $\mathrm{SiO}_{2}$, together make up between 16 and 66 $\mathrm{wt} \%$ of the bulk mass of the weathered coal samples. The strong positive correlation between these two species of oxide in weathered coal samples $\left(R^{2}\right.$ of 0.92 ; Figure 6a) at an average ratio of 0.87 , is strongly indicative of the dominance of kaolinite as the main inorganic mineral phase in the examined coals. This is confirmed by our XRD results (not shown here) and is also in full agreement with compositional information from most South African coals [35]. Conversely, the clearly antithetic relationship between $\mathrm{SiO}_{2}$ content and the LOI value as an effective expression of bulk organic matter content $\left(\mathrm{R}^{2}\right.$ of 0.95 ; Figure $6 \mathrm{~b}$ ), marks the closure effect between the two main constituents of weathered coal, namely organic carbon and kaolinite.
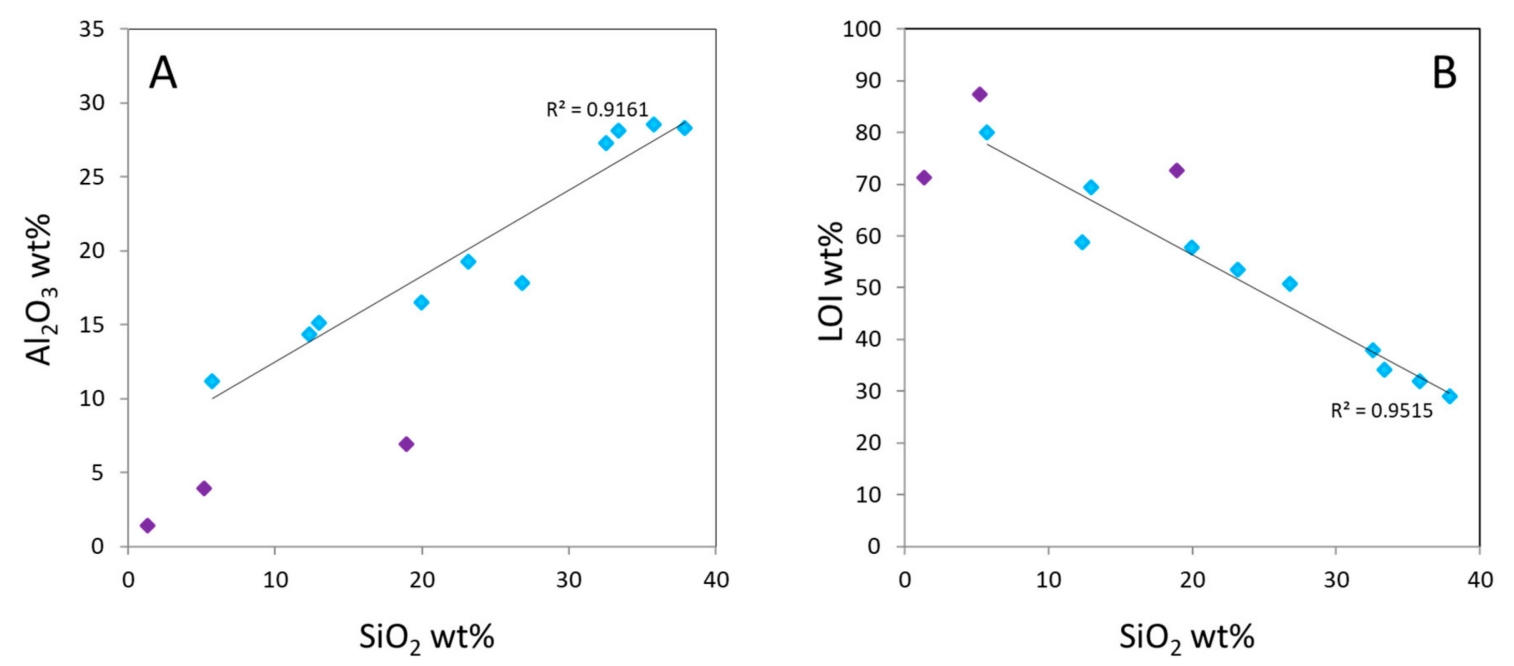

Figure 6. Binary relationship between (A) bulk $\mathrm{Al}_{2} \mathrm{O}_{3}$ and $\mathrm{SiO}_{2}$ contents and, (B) $\mathrm{SiO}_{2}$ contents and corresponding loss on ignition (LOI) values, for weathered (light blue markers) and hard coal (dark blue markers) samples. Correlation trajectories and coefficients shown for the weathered sample set only.

Apart from the fluctuating bulk Fe-oxide contents across the weathered coal profile, which reflect the breakdown of correspondingly variable pre-existing pyrite abundances, the other constituent in weathered coal samples that reaches average concentration above $1 \mathrm{wt} \%$ is titanium dioxide $\left(\mathrm{TiO}_{2}\right)$. Previous comprehensive observations of the mineralogy of coals in South Africa [35] report minor concentrations of the mineral rutile in roof and floor lithologies. Since the $\mathrm{TiO}_{2}$ abundances here are very low and thus undetectable through the XRD technique, the presence of a $\mathrm{TiO}_{2}$ polymorph such as rutile or anatase could not be verified for the Kromdraai profile samples and requires microanalytical techniques not employed here. Further constraints in this regard, however, will be provided below in our assessment of trace element abundances.

All other major element oxide components in the weathered coal samples are present in very low concentrations and thus will not be discussed further, except for bulk calcium oxide ( $\mathrm{CaO})$. $\mathrm{CaO}$ values are very low $(<0.5 \mathrm{wt} \%)$, indicating that if primary carbonate minerals (such as dolomite) were present in the coals, they must have broken down almost wholesale during chemical weathering. Increased acidity produced by oxidation of pyrite-bound and organic-bound sulphur alike, would have promoted such carbonate solubility. We note the strong covariance $\left(R^{2}=0.85\right)$ between calcium oxide and the organic fraction of weathered coal as approximated by the LOI values (Figure 7). By contrast, no statistical relationship exists between $\mathrm{CaO}$ and $\mathrm{P}_{2} \mathrm{O}_{5}$ or $\mathrm{MgO}$ values that would, respectively, signify the occurrence of minor apatite or dolomite. A significant proportion of dehydrated gypsum as 
basanite $\left(\mathrm{CaSO}_{4} \cdot \frac{1}{2} \mathrm{H}_{2} \mathrm{O}\right)$ has been reported from all South African reference coals after low temperature combustion, and this has been ascribed to the reaction of organic sulphur with organically associated calcium [35]. Since our samples have not undergone low-temperature combustion, we consider that reaction of sulphate ions with minor organic-bound Ca during weathering would have led to the formation of some secondary gypsum in our samples.

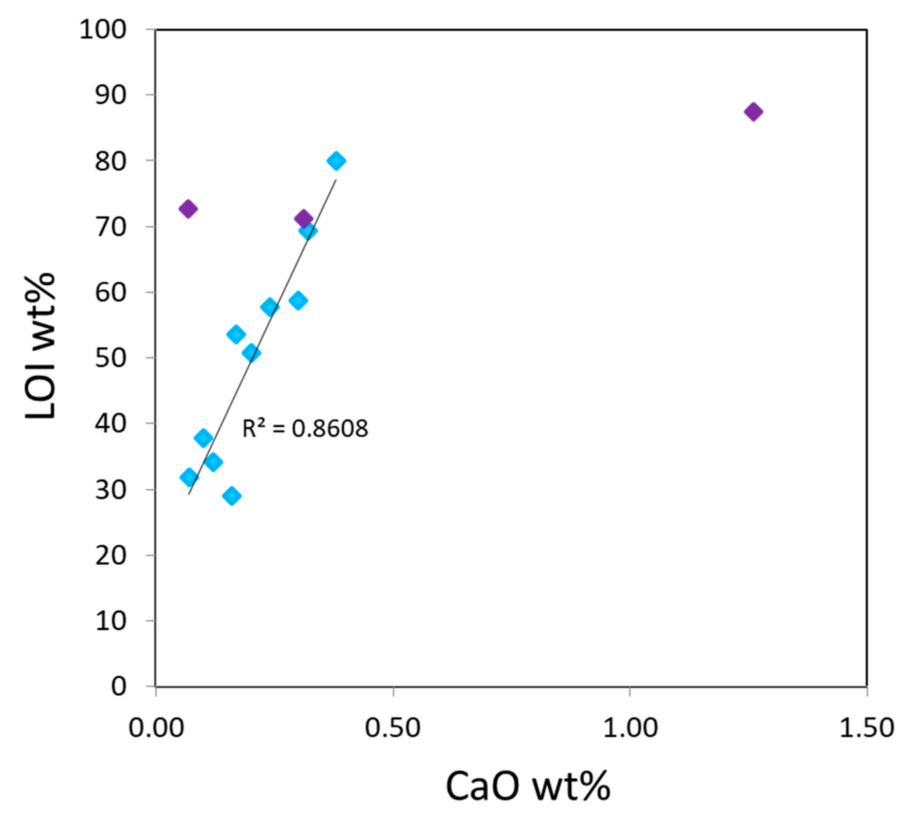

Figure 7. Binary relationship between bulk calcium oxide $(\mathrm{CaO})$ and corresponding LOI values, for weathered (light blue markers) and hard coal (dark blue markers) samples. Correlation trajectories and coefficients shown for the weathered sample set only.

With regard to selected minor and trace element abundances, the spidergram of Figure 8 illustrates the variability in both weathered and hard coal samples when normalized against average upper continental crust (UCC). The diagram permits the extraction of three key conclusions concerning these elements and their relative behavior during weathering: (1) abundances for hard coal samples display enrichments in most trace elements relative to UCC, with notable exceptions those of $\mathrm{Ti}, \mathrm{Rb}, \mathrm{Sr}$, and $\mathrm{Mn}$. (2) Compared to hard coal, weathered coal samples from the Kromdraai transect record enrichments in High Field Strength Elements (HFSE) such as $\mathrm{Ti}, \mathrm{Nb}$, and $\mathrm{Zr}$; the transition metal $\mathrm{Cr}$; and, to a lesser degree, the lanthanides and actinides analyzed for $(\mathrm{La}, \mathrm{Ce}, \mathrm{Nd}, \mathrm{Th}, \mathrm{Y})$. These elements are therefore regarded as having been immobile and thus passively enriched during chemical weathering. (3) The elements $\mathrm{Sr}, \mathrm{Ba}, \mathrm{Co}, \mathrm{Mn}$, and $\mathrm{Zn}$ conversely show the most significant relative depletion compared to hard coal, suggesting their strong mobility during weathering.

The depletions in trace alkali earths and selected transition metals can be attributed to the general instability of their most common mineral hosts in the chemical weathering environment, such as detrital feldspars, clays, and carbonate minerals. They therefore conform to the depletion in the weathered coal of major element oxides such as $\mathrm{CaO}, \mathrm{MgO}, \mathrm{Na}_{2} \mathrm{O}$, and $\mathrm{K}_{2} \mathrm{O}$, with which they share similar solubility behavior. Mobility of alkalis and alkali earths is augmented particularly under conditions of low $\mathrm{pH}$ induced by organic matter and pyrite oxidation and resultant increased acidity during weathering. The weathered coal samples therefore invariably become impoverished in all above species compared to hard coal. By contrast, the HFSE, Cr, selected lanthanides and actinides, are associated with detrital minerals that are known to be more resilient to chemical weathering, such as $\mathrm{TiO}_{2}$ polymorphs (e.g., rutile), zircon and chromite. The occurrence of particularly a $\mathrm{TiO}_{2}$ mineral species is supported by the strong and established positive correlation between $\mathrm{TiO}_{2}$ and the element $\mathrm{Nb}$ (Figure $9 \mathrm{a}$ ) as typically known to characterize the mineral rutile. Noteworthy here is also the good 
positive relationship of Figure $9 \mathrm{~b}$ between $\mathrm{Ni}$ and LOI as an expression of the bulk organic fraction of the samples, which suggests that this metal is probably also stable and conservatively retained in the weathering environment albeit in association with a secondary organo-metallic complex.

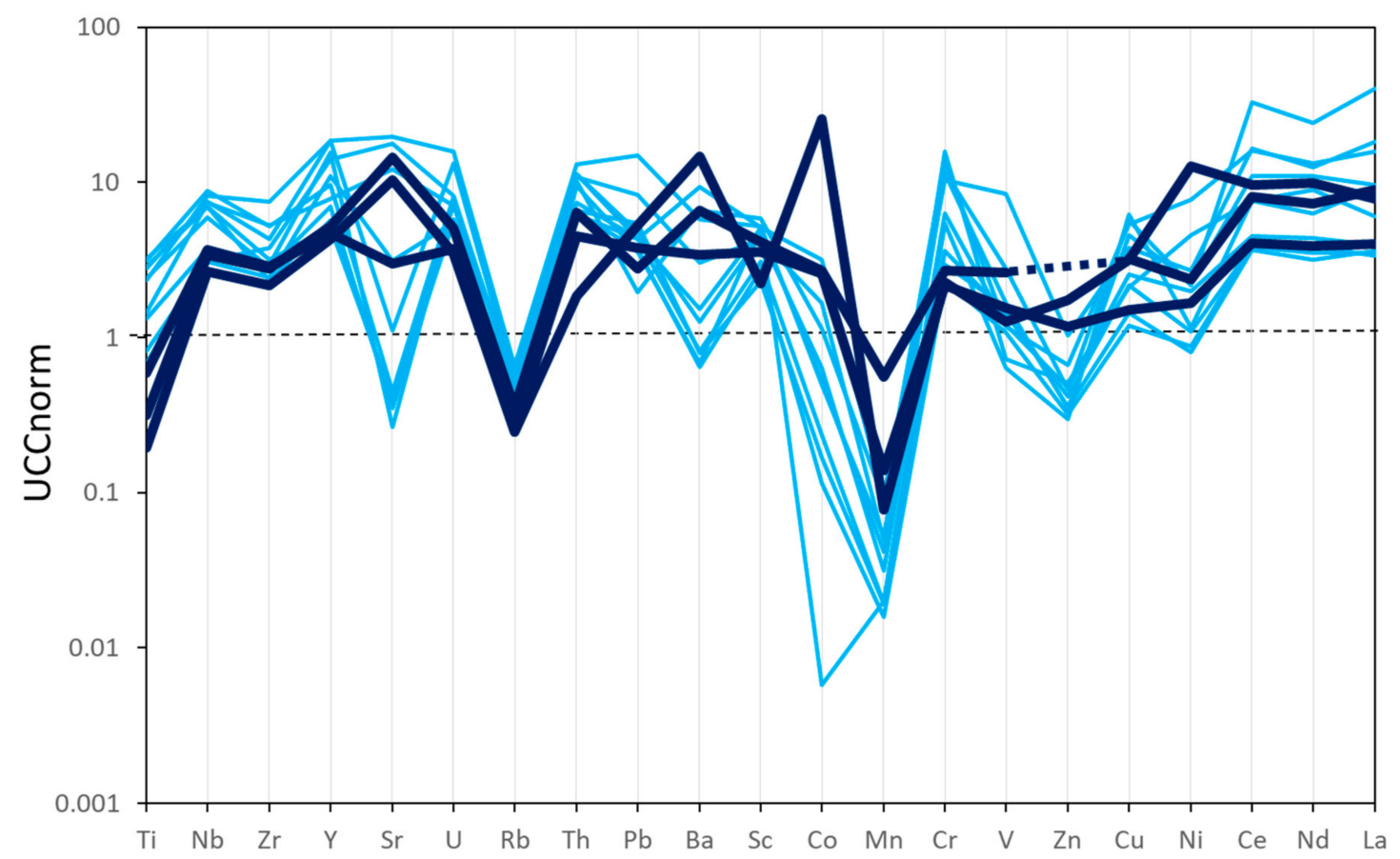

Figure 8. Upper continental crust (UCC)—normalized spidergrams for the minor and trace element composition of weathered (thin light blue) and hard (dense dark blue) coal samples.
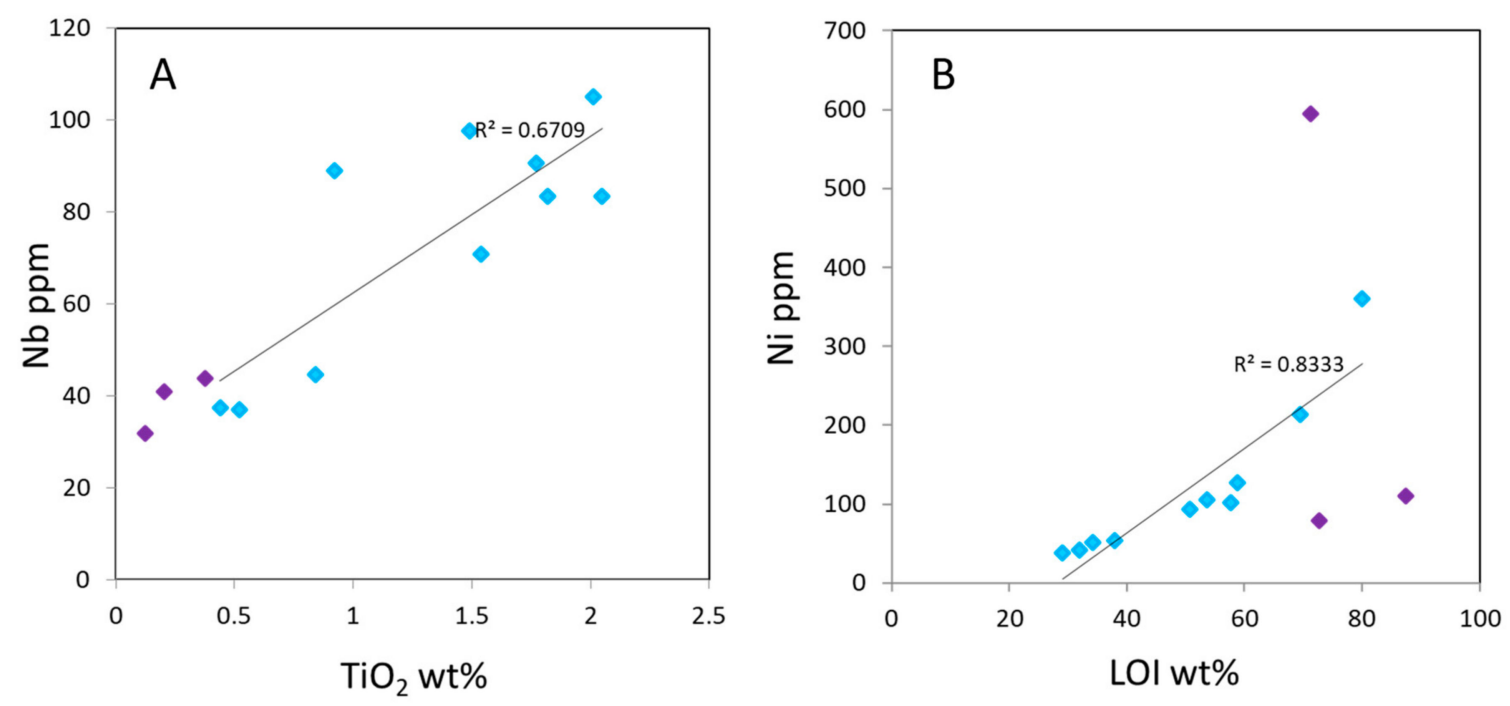

Figure 9. Binary relationships between $(\mathbf{A})$ bulk $\mathrm{TiO}_{2}$ and $\mathrm{Nb}$, and (B) bulk $\mathrm{Ni}$ and LOI values, for weathered (light blue markers) and hard coal (dark blue markers) samples. Correlation trajectories and coefficients shown for the weathered sample set only.

\subsection{Pyrolysis GC-MS}

A typical pyrolysis GC-MS analysis of hard coal and weathered coal is illustrated in Figure 10. Pyrolysis of hard coal produced a total ion chromatogram very different from that of weathered coal with relatively intense phenols, naphthalenes, and other polynuclear aromatic hydrocarbons (compare Figure 10a,b with MS results for hard coal pretreated with strong acid and extracted with 
tetrahydrofuran) [36]. Only alkanes, alkenes, dibenzofuran, and phenol were common in pyrolysates from both the hard and weathered coal samples. Total ion chromatograms from weathered coal samples showed a predominance of C-16 and C-18 fatty acids and pyrolysis released mostly compounds with these functional groups, and some aromatic compounds (Figure 10b). Variations within the weathered coal samples were evident, such as a hopene series present only in sample 6 , and esters of palmitic (C16:0) and stearic (C18:0) acids in five of the samples $(1,4,5,7$, and 9$)$. The presence in sample 6 of $17 \alpha(\mathrm{H}), 21 \beta(\mathrm{H})$-homohopanes might indicate a high degree of geochemical maturity of this weathered coal $[37,38]$. However, since these indicator compounds typically originate from bacterial membrane lipids and were predominantly in the R,S- or $\alpha, \beta$ - stereochemical configuration, any bacterial activity most likely occurred prior to transformation of hard coal to weathered coal.

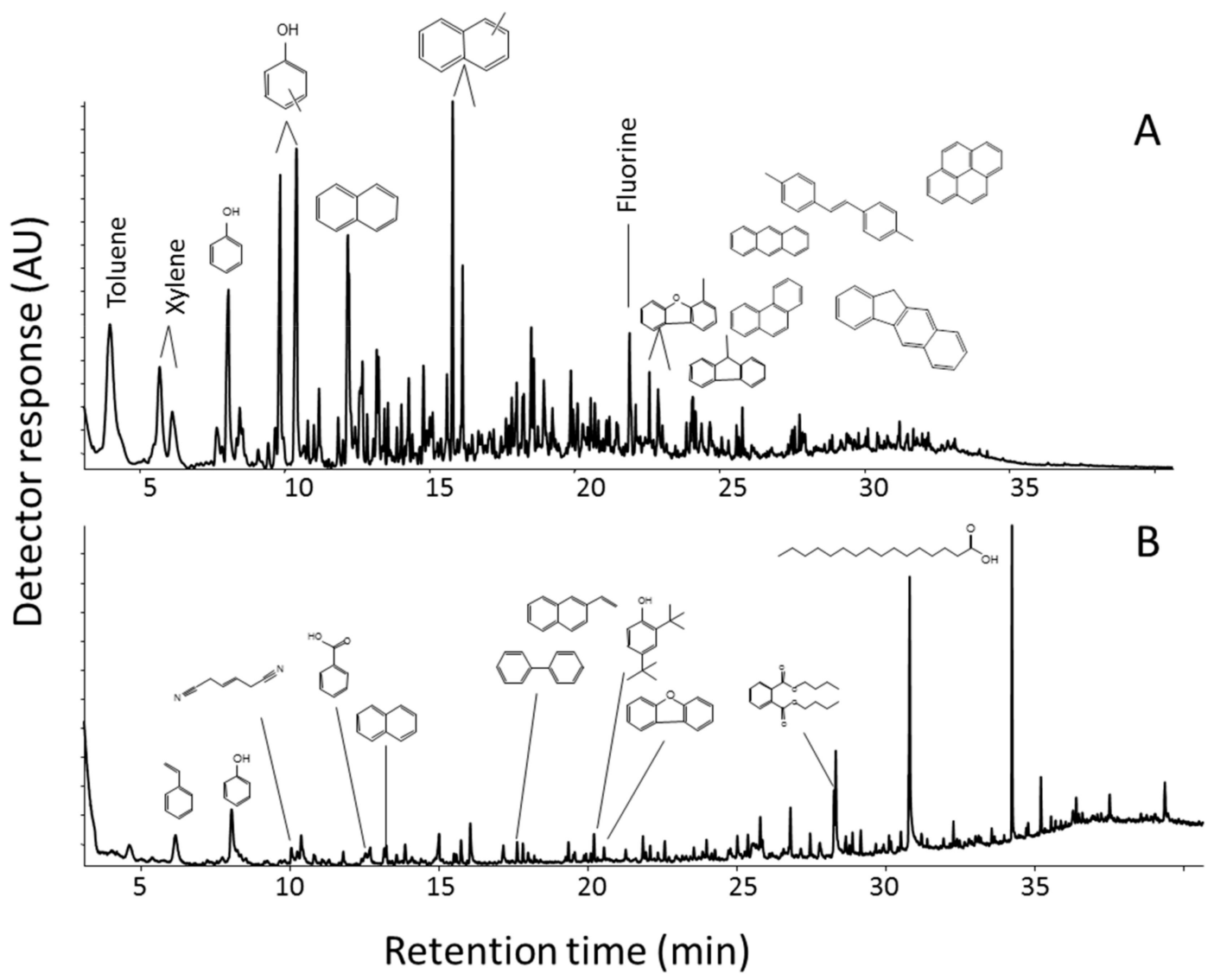

Figure 10. Pyrolysis gas chromatography-mass spectrometry analysis of bituminous hard coal (A) and representative outcrop weathered coal (B) samples from Kromdraai, Landau Colliery.

Ratios of the various products of pyrolysis showed some variability in weathered coal, but without any definitive trend. For example, the $n$-alkane:alkene ratio varied from 0.4 to 3 in weathered coal, while this ratio in hard coal was only slightly above 3 (Figure 11). The ratio phenol:naphthalene was approximately 2 in all of the weathered coal samples except sample 10, where this ratio was 7 . In hard coal samples, the phenol:naphthalene ratio was much smaller at 0.1 (Figure 11) even though phenols in hard coal were far more prominent than in weathered coal (compare Figure 10a to Figure 10b). A decrease in the $n$-alkane:alkene ratio in weathered coal may reflect input alkenes derived from more recent sources like soil/plants/bacteria whereas the relatively high phenol:naphthalene ratio may have arisen due to leaching of the more water soluble phenols. Other pyrolysate components including nitrogenous compounds (e.g., 3-hexenedinitrile) and benzaldehyde were absent (or below the detection limit) in hard coal, and benzaldehyde was also absent in weathered coal sample 10 (Figure 11). 


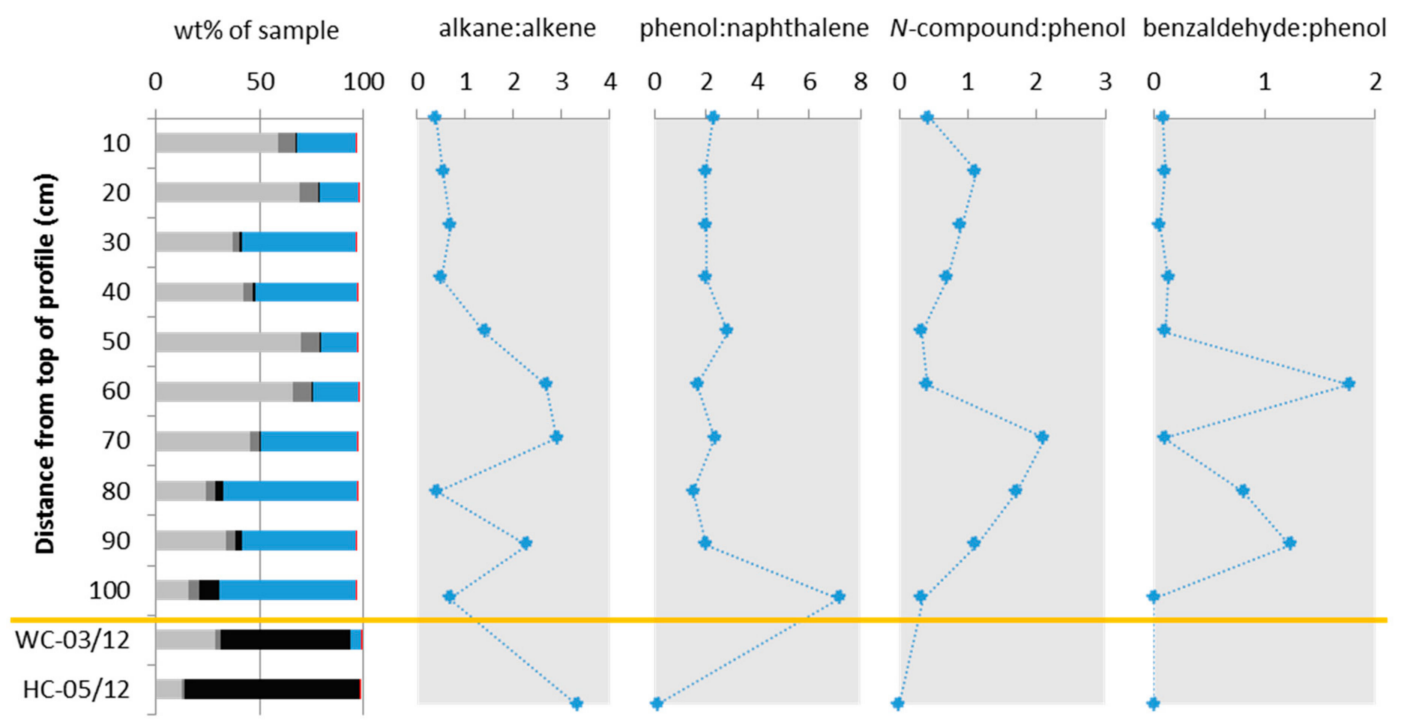

Figure 11. Pyrolysate ratios in samples of weathered coal outcrop along the profile and in the hard coal sample, HC-05/12.

\subsection{On the In Situ Formation of Humic-Like Substances}

In an effort to obtain confirmatory evidence for in situ formation of HA-like substances in coal discard treated with Fungcoal [26,29,30], substrate from commercial scale trials at Kleinkopje, Greenside and Kromdraai was collected 18 months after trial initiation and the samples analyzed geochemically. Similarly, substrate from small-scale trials treated with Fungcoal and initiated in 2006, were collected and analyzed geochemically (Figure 12).

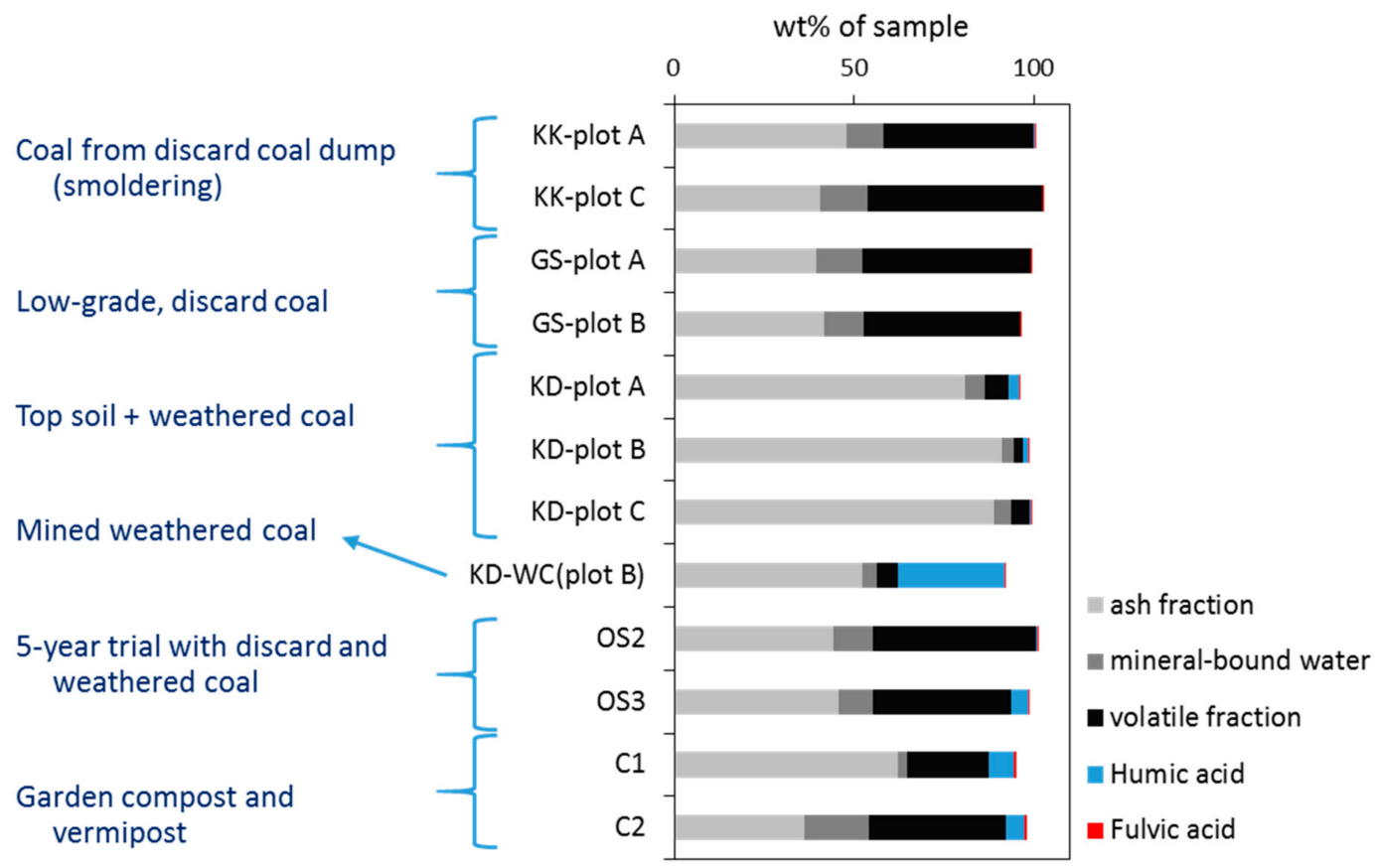

Figure 12. Humic, fulvic, volatile (humin), and ash content and composition of coal discard after treatment with Fungcoal. Discard material was treated with Fungcoal on a large scale without co-substrate (KK, Klippan Kleinkopje); with a waste coal co-substrate (GS); with a weathered coal co-substrate (KD); or on a small-scale (OS, Kleinkopje roofcoal dump). Samples were collected at 18 (large-scale) and 72 (small-scale) months after trial initiation, analyzed geochemically, and the HA-like substance content compared to HA extracts of garden compost and vermipost. 
Substrate from large-scale commercial trials at Kleinkopje (Klippan Dump; Fungcoal, no co-substrate) and Greenside (Fungcoal + waste coal co-substrate) contained no HA-like substances extractable with $\mathrm{NaOH}$. The ash fraction, at approximately $40 \mathrm{wt} \%$, was large compared to hard coal, which was expected. Substrate from Kromdraai (KD) opencast spoil (Fungcoal + weathered coal co-substrate) contained 1-3 wt \% HA, while substrate from the small-scale trial site on the Kleinkopje Roofcoal dump (OS; initiated in September 2006) contained 0.3-5 wt\% (Figure 12). It is suspected that this HA-like substance was most likely derived from the weathered coal co-substrate used to support Fungcoal application, since treatment without added weathered coal (KD-Plot C) showed negligible HA-like substance enrichment. The HA extracted from the weathered coal sample from plot B (KD-WC) confirmed this co-substrate as a source of HA. Interestingly, the HA-like substance content of substrate treated with Fungcoal + weathered coal co-substrate from both large- and small-scale trials was similar to that of the compost references which contained 5-7 wt \% HA-like matter, and 0.8-0.9 $\mathrm{wt} \%$ fulvic acid and an ash fraction of $36-62 \mathrm{wt} \%$ (Figure 12).

\section{Discussion and Conclusions}

Results presented in this manuscript represent to our knowledge the first characterization of a naturally occurring weathered coal seam in South Africa. In brief, weathered coal (No 2 Seam, Kromdraai Section, Landau Colliery) has decreased volatile material and increased humics, ash, and mineral bound water in comparison to hard (bituminous) coal. These changes occur coincident with decreased elemental $\mathrm{C}, \mathrm{N}$, and $\mathrm{H}$ contents, and a substantial increase in elemental $\mathrm{O}$ concentration. No apparent stoichiometric relationship between sulphur and iron oxide content of weathered coal could be discerned suggesting little residual pyrite in this material and a dominance of oxy-hydroxides of Fe. Trace element composition was mirrored in hard coal indicating that enrichment proceeded in concert with weathering. The organic fraction of hard coal differed markedly from that of weathered coal and contained substantial phenols, naphthalenes, and other polynuclear aromatic hydrocarbons. Weathered coal by comparison, was enriched with C-16 and C-18 fatty acids and hopanoids of the $17 \alpha(\mathrm{H}), 21 \beta(\mathrm{H})$-homohopanes type. Furthermore, analysis revealed that HA-like material is indeed generated from the coal fraction. The process appears to entail enrichment of coal with inorganic elements in which kaolinite becomes the dominant clay mineral in weathered coal. Enrichment of the parent coal with trace elements is also evident and appears to occur more readily as the degree of weathering progresses.

The above characterization notwithstanding, use of weathered coal as a co-substrate in bioprocess technologies such as Fungcoal for land rehabilitation requires further study [25]. In particular, information on the distribution and abundance of reacting mineral species within this material is needed. Additionally, its suitability as a carbon source to support mycorrhizal fungi that underpin fungal-plant mutualism $[25,26]$ needs further elaboration. Such studies should focus on deriving data to predict the extent of acidification (where there is presence of pyrite) and neutralization (presence of carbonates and aluminosilicates) potential [35], determine the critical threshold levels of heavy metals $[39,40]$, and address soil structure, microbe populations, and nutrient cycling in order to transform the land from its disturbed condition to a self-sustaining ecosystem. Studies on the mobility and bioavailability of heavy metals from weathering of stockpiled coal and coal spoil show that readily diffusable and easily leached metals are retained in the weathered material by complexation with organic compounds and/or by adsorption to an amorphous iron oxyhydroxide colloid [41]. Thus, until the complexation mechanisms that occur during weathering are better understood, infiltration of heavy metals remains a risk [41]. Similarly, a deeper understanding of the fate of the organic material in weathered coal is needed in order to optimize the amount of this material needed for successful large-scale rehabilitation of discard dumps and opencast spoil particularly where other low-grade coals are readily available. The fate of organic carbon in naturally weathered coal seams appears to differ considerably from that of coal that has been exposed to conditions that cause weathering $[16,17]$. Thus, and since Kromdraai weathered coal is a finite resource and limiting in the roll out of rehabilitation 
strategies like Fungcoal, access to other weathered coal seams is necessary both as a source of humic material for use in land rehabilitation and to meet the growing demand for humics in the preparation and use of biofertilizers [25,42].

Supplementary Materials: The supplementary data file is available online at http://www.mdpi.com/2075-163X/9/ 12/772/s1.

Author Contributions: Y.v.B. and A.K.C. conceptualized and executed the research; H.T. contributed towards partial data acquisition, evaluation, interpretation, and writing/editing of the manuscript.

Funding: Anglo American Thermal Coal, South Africa, the National Research Foundation, South Africa (IFR1202220169, Grant No: 80879) and the Technology for Human Resources for Industry Programme (THRIP; TP13070820781, UID 90252) are acknowledged for financial support.

Acknowledgments: The authors are very grateful to Henk Lodewijks (Mine Closure Manager, Anglo American Coal) for championing this research and development study. The technical and laboratory support from Dave Render, Michelle Isaacs, Andile Magaba, Olwethu Baba, and Nomaindia Toto of EBRU, is also gratefully acknowledged. Assistance from mine personnel at Greenside Colliery, Kleinkopje Colliery, and Kromdraai Opencast, Landau Colliery is sincerely appreciated.

Conflicts of Interest: The authors declare no conflict of interest.

\section{References}

1. Couch, G.R. Biotechnology and Coal; IEA Coal Research: London, UK, 1987.

2. Truter, W.J.; Rethman, N.F.G.; Potgieter, C.E.; Kruger, R.A. Re-Vegetation of Cover Soils and Coal Discard Material Ameliorated with Class F Fly Ash. Chapter 6. Available online: https://repository.up.ac.za/bitstream/ handle/2263/25594/Complete.pdf?sequence=8\#page=177 (accessed on 2 February 2016).

3. Claassens, S.; Jansen van Rensburg, P.J.; van Rensburg, L. Soil microbial community structure of coal mine discard under rehabilitation. Water Air Soil Pollut. 2006, 174, 355-366. [CrossRef]

4. Limpitlaw, D.; Aken, M.; Lodewijks, H.; Viljoen, J. Post mining rehabilitation, land use and pollution at collieries in South Africa. In Colloquium: Sustainable Development in the Life of Coal Mining; South African Institute of Mining and Metallurgy: Boksburg, South Africa, 2005; pp. 1-10.

5. Limpitlaw, D.; Briel, A. Post-mining land use opportunities in developing countries-A review. J. S. Afr. Inst. Min. Met. 2015, 114, 1-5.

6. Falcon, R.M.S. Macro- and micro-factors affecting coal-seam quality and distribution in southern Africa with particular reference to the No. 2 seam, Witbank coalfield, South Africa. Int. J. Coal Geol. 1989, 12, 681-731. [CrossRef]

7. Smith, D.A.M.; Whittaker, R.R.L.G. The Coalfields of Southern Africa: An Introduction. In Mineral Deposits of Southern Africa; Anhaeusser, C.R., Maske, S., Eds.; Geological Society of Southern Africa: Johannesburg, South Africa, 1986; Volume II, pp. 1875-1878.

8. Falcon, R.M.S. A brief review of the origin, formation and distribution of coal in Southern Africa. In Mineral Deposits of Southern Africa; Anhaeusser, C.R., Maske, S., Eds.; Geological Society of South Africa: Johannesburg, South Africa, 1986; Volume II, pp. 1879-1898.

9. Snyman, C.P. The role of coal petrography in understanding the properties of South African coal. Int. J. Coal Geol. 1989, 14, 83-101. [CrossRef]

10. Snyman, C.P.; Barclay, J. The coalification of South African coal. Int. J. Coal Geol. 1989, 13, 375-390. [CrossRef]

11. Snyman, C.P.; Van Vuuren, M.C.J.; Barnard, J.M. Chemical and Physical Characteristics of South African Coal and a Suggested Classification System; Coal Report no. 8306; National Institute for Coal Research: Pretoria, South Africa, 1984; pp. 1-63.

12. Snyman, C.P.; Botha, W.J. Coal in South Africa. J. Afr. Earth Sci. 1993, 16, 171-180. [CrossRef]

13. Department of Energy. National Inventory Discard and DuffCoal-2001: Summary Report; Republic of South Africa: Pretoria, South Africa, 2001. Available online: http://www.energy.gov.za/Coal/coal_discard_report.pdf (accessed on 1 August 2019).

14. Carlsen, L.; Christiansen, J.V. Flash pyrolysis of coals-A new approach of classification. J. Anal. Appl. Pyrolysis 1995, 35, 77-91. [CrossRef]

15. Han, Z.; Kruge, M.A. Classification of torbanite and cannel coal: II. Insights from pyrolysis-GC/MS and multivariate statistical analysis. Int. J. Coal Geol. 1999, 38, 203-218. [CrossRef] 
16. Ingram, G.R.; Rimstidt, J.D. Natural weathering of coal. Fuel 1984, 63, 292-296. [CrossRef]

17. Kurková, M.; Klika, Z.; Kliková, C.; Havel, J. Humic acids from oxidized coals: I. Elemental composition, titration curves, heavy metals in HA samples, nuclear magnetic resonance spectra of HAs and infrared spectroscopy. Chemosphere 2004, 54, 1237-1245. [CrossRef]

18. Yun, Y.; Meuzelaar, H.L.C. Development of a reliable coal oxidation (weathering) index-Slurry $\mathrm{pH}$ and its application. Fuel Proc. Technol. 1991, 27, 179-202. [CrossRef]

19. Yun, Y.; Jakab, E.; McClennen, W.H.; Hill, G.R.; Meuzelaar, H.L.C. Role of aliphatic and aromatic coal structures and macerals in low temperature oxidation processes. ACS Div. Fuel Chem. Prepr. 1987, 32, 129-137.

20. Cowan, A.K.; Lodewijks, H.M.; Sekhohola, L.M.; Edeki, O.G. In situ bioremediation of South African coal discard dumps. In Mine Closure 2016_Proceedings; Fourie, A.B., Tibbett, M., Eds.; Australian Centre for Geomechanics: Perth, Australia, 2016; pp. 501-509. ISBN 978-0-9924810-4-9.

21. Igbinigie, E.E.; Atkins, S.; van Breugel, Y.; van Dyke, S.; Davies-Coleman, M.T.; Rose, P.D. Fungal biodegradation of hard coal by a newly reported isolate, Neosartorya fischeri. Biotechnol. J. 2008, 3, 1407-1416. [CrossRef]

22. Igbinigie, E.E.; Mutambanengwe, C.Z.; Rose, P.D. Phyto-bioconversion of hard coal in the Cyanodon dactylon/coal rhizosphere. Biotechnol. J. 2010, 5, 292-303. [CrossRef]

23. Sekhohola, L.M.; Isaacs, M.L.; Cowan, A.K. Fungal colonisation and enzyme-mediated metabolism of waste coal by Neosartorya fischeri strain ECCN 84. Biosci. Biotech. Biochem. 2014, 78, 1797-1802. [CrossRef]

24. Mukasa-Mugerwa, T.T.; Dames, J.F.; Rose, P.D. The role of a plant/fungal consortium in the degradation of bituminous hard coal. Biodegradation 2011, 22, 129-141. [CrossRef]

25. Sekhohola, L.M.; Igbinigie, E.E.; Cowan, A.K. Biological degradation and solubilisation of coal. Biodegrad 2013, 24, 305-318. [CrossRef]

26. Sekhohola, L.M.; Cowan, A.K. Biological conversion of low-grade coal discard to a humic substance-enriched soil-like material. Int. J. Coal Sci. Technol. 2017, 4, 183-190. [CrossRef]

27. Amir, S.; Hafidi, M.; Lemee, L.; Merlina, G.; Guiresse, M.; Pinelli, E.; Revel, J.C.; Bailly, J.R.; Ambles, A. Structural characterization of humic acids, extracted from sewage sludge during composting, by thermochemolysis-gas chromatography-mass spectrometry. Proc. Biochem. 2006, 41, 410-422. [CrossRef]

28. Iglesias, M.J.; del Río, J.C.; Laggoun-Défarge, F.; Cuesta, M.J.; SuárezRuiz, I. Control of the chemical structure of perhydrous coals. FTIR and Py-GC/MS investigations. J. Anal. Appl. Pyrolysis 2002, 62, 1-34. [CrossRef]

29. McDonald, S.; Bishop, A.G.; Prenzler, P.D.; Robards, K. Analytical chemistry of freshwater humic substances. Anal. Chim. Acta 2004, 527, 105-124. [CrossRef]

30. Martin, F.; González-Vila, F.J.; del Rio, J.C.; Verdejo, T. Pyrolysis derivatization of humic substances. 1. Pyrolysis of fulvic acids in the presence of tetramethylammonium hydroxide. J. Anal. Appl. Pyrolysis 1994, 28, 71-80. [CrossRef]

31. Lehtonen, T.; Peuravuori, J.; Pihlaja, K. Characterisation of lake-aquatic humic matter isolated with two different sorbing solid techniques: Tetramethylammonium hydroxide treatment and pyrolysis-gas chromatography/mass spectrometry. Anal. Chim. Acta 2000, 424, 91-103. [CrossRef]

32. Lehtonen, T.; Peuravuori, J.; Pihlaja, K. Degradation of TMAH treated aquatic humic matter at different temperatures. J. Anal. Appl. Pyrolysis 2000, 55, 151-160. [CrossRef]

33. Fabbri, D.; Vassura, I.; Snape, C.E. Simple off-line flash pyrolysis procedure with in situ silylation for the analysis of hydroxybenzenes in humic acids and coals. J. Chromatogr. A 2002, 967, 235-242. [CrossRef]

34. Lo, H.B.; Cardott, B.J. Detection of natural weathering of Upper McAlester coal and Woodford Shale, Oklahoma, U.S.A. Org. Geochem. 1995, 22, 73-83. [CrossRef]

35. Pinetown, K.L.; Ward, C.R.; van der Westhuizen, W.A. Quantitative evaluation of minerals in coal deposits in the Witbank and Highveld Coalfields, and the potential impact on acid mine drainage. Int. J. Coal Geol. 2007, 70, 166-183. [CrossRef]

36. Hofrichter, M.; Fritsche, W. Depolymerization of low-rank coal by extracellular fungal enzyme systems. II. The ligninolytic enzymes of the coal-humic-acid-depolymerizing fungus Nematoloma frowardii b19. Appl. Microbiol. Biotechnol. 1997, 47, 419-424. [CrossRef]

37. Peters, K.E.; Walters, C.C.; Moldowan, J.M. The Biomarker Guide. Volume 2. Biomarkers and Isotopes in Petroleum Systems and Earth History, 2nd ed.; University Press: Cambridge, UK, 2005. 
38. Tarozo, R.; Frena, M.; Madureira, L.A.S. Geochemical markers as a tool to assess sedimentary organic matter sources of the Laguna Estuarine System, South Brazil: Aliphatic and polycyclic aromatic hydrocarbons. J. Braz. Chem. Soc. 2010, 21, 2308-2318. [CrossRef]

39. Kabata-Pendias, A.; Pendias, H. Trace Elements in Soils and Plants; CRC Press, Inc.: Boca Raton, FL, USA, 1984.

40. Basta, N.T.; Ryan, J.A.; Chaney, R.L. Trace element chemistry in residual-treated soil: Key concepts and metal bioavailability. J. Environ. Qual. 2005, 34, 49-63. [CrossRef]

41. Dang, Z.; Liu, C.; Haigh, M.J. Mobility of heavy metals associated with the natural weathering of coal mine spoils. Environ. Pollut. 2002, 118, 419-426. [CrossRef]

42. Canellas, L.P.; Dobbss, L.B.; Oliveira, A.L.; Chagas, J.G.; Aguiar, N.O.; Rumjanek, V.M.; Novotny, E.H.; Olivares, F.L.; Spaccini, R.; Piccolo, A. Chemical properties of humic matter as related to induction of plant lateral roots. Eur. J. Soil Sci. 2012, 63, 315-324. [CrossRef]

(C) 2019 by the authors. Licensee MDPI, Basel, Switzerland. This article is an open access article distributed under the terms and conditions of the Creative Commons Attribution (CC BY) license (http://creativecommons.org/licenses/by/4.0/). 